Jurnal Sewaka Bhakti

Lembaga Penelitian dan Pengabdian Kepada Masyarakat

Universitas Hindu Indonesia Denpasar

Volume 4, Nomor 1 April 2020

ISSN: 2654-2935 (Online)

https://ejournal.unhi.ac.id/index.php/sewakabhakti

\title{
PERANAN PEREMPUAN DALAM MENINGKATKAN PENDAPATAN KELUARGA DI DESA PINGGAN KINTAMANI
}

\author{
Ni Luh Kardini \\ Fakultas Ekonomi, Universitas Mahendradatta, Jl. Ken Arok No.12, Peguyangan, Denpasar \\ Utara, Kota Denpasar, Bali 80115 \\ Telp/Fax: (0361) 434827/0361-249471 \\ Email: kardini.mahayoga@gmail.com
}

\begin{abstract}
Abstrak
Keluarga merupakan suatu lembaga sosial yang paling besar perannya bagi kesejahteraan sosial dan kelestarian anggota-anggotanya terutama anak-anaknya. Pelaku penting dalam dinamika rumah tangga adalah perempuan dalam artian perempuan menguasai pengelolaan keuangan, redistribusi pendapatan, alokasi konsumsi. Kedudukan perempuan dalam keluarga/ rumah tangga secara umum memiliki wewenang dan tanggung jawab yang berbeda dari pria yang merupakan kepala keluarga. Perempuan diharapkan mampu memberikan kontribusi kepada keluarganya dan berperan dalam meningkatkan pendapatan keluarga. Sehingga ekonomi keluarga menjadi seimbang. Desa pinggan yang terkenal dengan destinasi pariwisata yang terkenal dengan sebutan negeri diatas awan. Desa Pinggan Kintamani menjadi lokasi liburan yang tidak kalah menariknya di Pulau Bali.

Kata Kunci : Peranan Perempuan, Keluarga, Desa Pinggan
\end{abstract}

\section{Pendahuluan}

Kabupaten Bangli adalah sebuah kabupaten yang terletak di provinsi Bali. Bangli adalah satu-satunya kabupaten di Bali yang tidak memiliki pantai (terkurung daratan) dan Bangli juga termasuk daerah terkecil di provinsi bali karena hanya memiliki 4 kecamatan yaitu kecamatan Bangli, Susut, Tembuku dan terakhir yaitu kecamatan Kintamani. Luas wilayah yang paling tinggi dari 4 kecamatan tersebut adalah Kintamani. Dalam penelitian kersos kali ini saya mengambil contoh di Kabupaten Bangli tepatnya di Desa Pinggan Kintamani.

Desa pinggan yang terkenal dengan destinasi pariwisata yang terkenal dengan sebutan negeri diatas awan. Desa Pinggan Kintamani menjadi lokasi liburan yang tidak kalah menariknya di Pulau Bali. Apalagi kalau Anda adalah orang yang suka berburu pemandangan sunrise. Tempat ini menyajikan pemandangan matahari terbit di ufuk timur dari lokasinya yang berupa dataran tinggi. Wilayah Kintamani memang terkenal akan kesejukan udaranya. Tak heran jika Kintamani selalu dikunjungi wisatawan untuk mendapatkan keindahan 
pemandangan alam pegunungan di Bali. Pemandangan Gunung Batur beserta danaunya terlihat sangat memukau tatkala dilihat dari Kintamani. Terdapat sebuah desa di Kintamani yang memiliki spot terbaik untuk melihat keindahan Bali di pagi hari yakni Desa Pinggan.

Desa yang berada di wilayah Kintamani ini menyajikan pemandangan desa berkabut berlatar pegunungan yang cantik. Tentu pengalaman ini menjadi pengalaman seru tatkala Anda sengaja datang ke Desa Pinggan. Selama ini hanya pantai yang menjadi lokasi favorit untuk menyaksikan fenomena matahari terbit. Namun anggapan itu seketika berubah tatkala keindahan sunrise yang tak terbantahkan juga terpampang di Desa Pinggan. Jika Anda ingin menikmati indahnya matahari terbit di Desa Pinggan, Anda bisa datang sekira pukul 05.30 WITA. Ini karena fenomena cantiknya sunrise akan mulai terlihat di Desa Pinggan mulai pukul 06.00 WITA. Bila Anda berangkat dari Denpasar, maka waktu yang diperlukan untuk mencapai lokasi Desa Pinggan sekitar 2 jam 15 menit. Jadi ketika Anda ingin melihat indahnya sunrise di Desa Pinggan, Keindahan sunrise di Desa Pinggan Kintamani ditambah semakin ciamik oleh adanya permadani kabut yang terhampar di areal pegunungan. Tampak di bawah adalah pemandangan areal persawahan yang samar-samar tertutup kabut.

Berada di Desa Pinggan yang bisa Anda lakukan adalah rileksasi menikmati segarnya udara pegunungan. Selain itu lokasi ini sangat indah jika dibalut dalam mata kamera. Tak heran jika banyak wisatawan yang datang ke Desa Pinggan selalu mengabadikan momen mereka di sini. Berwisata menikmati keindahan pagi di Desa Pinggan tidak perlu tiket masuk alias gratis. Desa pinggan memiliki luas tanah... yang memiliki ketinggian tanah $1400 \mathrm{~m}$, dan berjarak 15 $\mathrm{km}$ dari pusat pemerintahan kecamatan. Dan jarak dari ibu kota provinsi bali hamper $81 \mathrm{~km}$.

Selain fenomenanya yang indah Desa pinggan merupakan salah satu penghasil hasil tani terbesar di provinsi Bali. Yang dimana sebagian besar masyrarakat desa pinggan adalah seorang petani dan pengepul sayuran. Salah satu hasil tani terbesar di desa pinggan adalah labu siam yang dimana setiap harinya bisa memanen dan mengirim hasil taninya hampir 10 ton/ hari. Hasil tani akan di kirim ke seluruh Indonesia bahkan juga ada yang dikirim keluar negri.

Masyarakat desa pinggan berjumlah 2018 orang. Dengan jenis klamin laki - laki 1012 orang, perempuan 1006 orang. Dengan jumlah kepala keluarga 677 KK. Dari $100 \%$ masyarakat desa pinggan hampir $85 \%$ adalah seorang petani, $10 \%$ pedagang, $5 \%$ pegawai. 
Dari jumlah 1006 perempuan yang ada di desa pinggan. Di samping menjalankan tanggung jawabnya sebagai seorang ibu rumah tangga mereka juga berperan penting dalam meningkatkan pendapatan keluarga di desa pinggan. Karena hampir semua perempuan desa pinggan bekerja baik itu sebagai petani, pedagang, maupun sebagai pegawai.

Keluarga adalah lingkungan terkecil dari masyarakat yang terdiri dari ayah, ibu, dan anak. Dari ketiga komponen kluarga tersebut memiliki peran dan tanggung jawab masing masing, seperti ayah merupakan kepala kluarga dan ibu memiliki peran sebagai istri bagi suami dan juga ibu bagi anak - anaknya.

Negara tidak mungkin sejahtera jika para perempuannya dibiarkan tertinggal, tersisihkan, dan tertindas. Seperti yang diungkaplkan oleh Vivekananda (M.Muhajir, 2005). Bahwa negara dan bangsa yang tidak menghormati kaum perempuannya tidak akan pernah menjadi besar, baik di saat ini maupun di masa depan. Di samping itu, peran perempuan juga telah diakomodir oleh segenap peraturan pembangunan nasional, seperti UU No. 6 tahun 2014 tentang desa, yang memuat keterlibatan perempuan yang sangat diperlukan bagi keberhasilan pembangunan desa. Peranan perempuan dalam pembangunan masyarakat, baik di perkotaan maupun di pedesaan perlu terus ditingkatkan terutama dalam menangani berbagai masalah sosial ekonomi yang diarahkan pada pemerataan hasil pembangunan, pengembangan sumberdaya manusia yang berkualitas dan pemeliharaan lingkungan (Indonesia, 2014).

Menurut Badan Koordinasi Keluarga Berencana Nasional /BKKBN (1992), keluarga mempunyai fungsi agama, sosial budaya, cinta dan kasih sayang, perlindungan, reproduksi, sosialisasi dan pendidikan, ekonomi, dan fungsi lingkungan (Hikmatuz Zoleha Sayyong, 2012). Fungsi pertama yang terdapat dalam keluarga adalah fungsi agama. Di dalam keluarga, kita dikenalkan dan diajarkan tentang keberadaan Tuhan yang maha Esa dan diajarkan cara beribadah yang benar. Disamping itu, dalam keluarga ditanamkan nilai-nilai agama dan sekaligus memberikan identitas agama kepada anak. Apabila di dalam menerapkan nilai-nilai agama dalam kehidupan sehari-hari berhasil maka dapat dikatakan mampu memberikan fondasi yang kuat bagi setiap anggota keluarganya. Fungsi cinta dan kasih sayang mengharuskan keluarga menjadi tempat untuk menciptakan suasana cinta dan kasih sayang dalam kehidupan berkeluarga, bermasyarakat, berbangsa dan bernegara. Dalam kehidupan keluarga, cinta kasih dan kasih sayang antara anggota keluarga akan dapat 
menumbuhkan rasa tanggung jawab terhadap keharmonisan keluarga tersebut. Dengan demikian, setiap anggota keluarga akan selalu menjaga komitmen yang telah dibuat bersama. Dalam kehidupan bermasyarakat dengan fungsi ini juga akan menimbulkan keharmonisan dalam bermasyarakat. Fungsi sosial budaya dalam keluarga mengajarkan bagaimana kita bersosialisasi dengan orang lain dan bagaimana cara kita menghargainya. Kita pribadi tidak bisa hidup tanpa orang lain karena kita butuh orang lain untuk bersosialisasi. Fungsi perlindungan dalam keluarga adalah melindungi anak dan keluarganya dari tindakan-tindakan yang tidak baik sehingga anggota keluarganya merasa aman dan terlindungi.

Tanggung jawab seorang ayah adalah berperan mencari nafkah untuk keluarga atau berkewajiban memenuhi kebutuhan sandang, pangan, papan, kesehatan, pendidikan dan menjaga keluarganya, dan istri berperan untuk mengurus rumah tangga, sebagai pengasuh dan pendidik anak - anaknya serta mengatur keperluan yang mencakup hal - hal yang ada di dalam rumah. Berbeda dengan peran anak dan keluarga, anak berperan sebagai pelengkap dalam keluarga, lebih tegasnya yaitu sebagai generasi penerus suatu keluarga.

\section{Tinjauan Pustaka}

\section{Pengertian Peran Perempuan}

Peran perempuan merupakan kegiaan atau aktivitas yang di kerjakan atau dianggap menjadi tanggung jawab perempuan, yaitu kegiatan istri seperti seputaran dapur (memasak), mengurus rumah, mengurus anak, dan melayani suami.

Dahulu mayoritas ibu - ibu tersebut tidak memiliki pekerjaan apa-apa selain mengurusi pekerjaan rumah sampai selesai. Secara umum di waktu senggangnya mayoritas ibu - ibu memilih menghabiskan waktunya hanya untuk ngerumpi dan mengurus pekerjaan rumah.

Di globalisasi ini para ibu - ibu sudah mulai meninggalkan kebiasaan ini dengan bekerja. Seperti yang dilakukan oleh ibu - ibu yang ada di desa pinggan, hampir seluruh perempuan yang ada di desa pinggan membantu suami dan keluarganya dengan bekerja. Pekerjaan yang di tekuni oleh perempuan di desa pinggan adalah sebagai seorang petani yang membantu sang suami untuk mengurusi ladangnya di desa pinggan. Hampir $80 \%$ pekerjaan perempuan di desa pinggan adalah seorang petani, $15 \%$ perempuan yang menekuni usaha 
berdagang, dan $5 \%$ perempuan bekerja sebagai seorang pegawai negri maupun swasta. Jadi hampir semua perempuan yang ada di desa pinggan adalah seorang pekerja untu meringankan beban keluarga dan bahkan perempuan di desa pinggan sangan berperan dalam meningkatkan pendapatan keluarga.

Dalam upaya mencapai hidup sejahtera, perempuan keluarga petani setiap hari berusaha agar segenap perannya baik sebagai seorang ibu rumah tangga, dan pencari nafhkah. Mereka mengatur waktu sedemikian rupa sehingga semua peran yang disandangnya dapat dilaksanakan dengan seimbang, kendati demikian pasti ada kendala yang akan dialami dalam melaksanakan peran tambahan tersebut. Salah satunya masalah penting jika perempuan memasuki sektor public atau bekerja di luar rumah tangga adalah pembinaan keluarga akan terbengkalai dan terabaikan. Karena itu meskipun perempuan di perbolehkan untuk bekerja disektor publik, dia tidak boleh menelantarkan sektor domestik dan pengasuhan anak anaknya.

\section{Peran Perempuan Dalam Keluarga}

Pelaku penting dalam dinamika rumah tangga adalah perempuan dalam artian perempuan menguasai pengelolaan keuangan, redistribusi pendapatan, alokasi konsumsi. Kedudukan perempuan dalam keluarga/ rumah tangga secara umum memiliki wewenang dan tanggung jawab yang berbeda dari pria yang merupakan kepala keluarga.

Tugas - tugas tersebut sesuai kapasitas yang di miliki oleh perempuan. Di sampingan itu, perempuan dan pria memiliki perbedaan tidak hanya dalam segi postur, melainkan juga pada cara berfikirnya, perempuan lebih cendrung pada perasaan sedangkan pria dominan pada rasional.

a. Peran sebagai istri

Dalam masyarakat, kedudukan perempuan sering menjadi identitas social. Status social tersebut dikarenakan aktifitas rutin yang dilakukan seseorang. Misalnya seseorang perempuan telah bersuami kemudian aktifitasnya hanya berada dilingkungan rumah, maka status sosialnya sebagai ibu rumah tangga.

b. Peran sebagai ibu 
Di antara aktifitas perempuan ialah memelihara rumah tangganya, membahagiakan suaminya, dan membentuk keluarga bahagia yang tentram, damai, penuh cinta dan kasih saying. Peran ibu sangan besar dalam mewujudkan kebahagiaan dan keutuhan keluarga. Dalam pembahasan ini, peran perempuan sebagai ibu yaitu:

1. Member ASI bagi anak - anaknya maksimal dua tahun.

2. Menjadi pendidik pertama bagi anak - anaknya.

3. Merawat dan menjaga dalam kehidupan awal anak baik dari segi pertumbuhan fisik, kecerdasan maupun spiritual.

Sejak anak lahir dari rahim ibu, maka ibulah yang lebih banyak mewarnai dan mengetahui perkembangan pribadi sang anak, prilaku dan ahlak anak untuk menjadi pribadi yang baik.

\section{Ekonomi Keluarga}

\section{Status Ekonomi Keluarga}

Pengertian kalimat "status ekonomi keluarga" Status berarti keadaan atau kedudukan (orang, badan) dalam berhubungan dengan masyarakat di sekelililingnya. Ekonomi berarti urusan keuangan rumah tangga (organisasi, negara) di masyarakat istilah ekonomi biasanya berhubungan dengan permasalahan kaya dan miskin, keluarga berarti ibu bapak dan anakanaknya satuan kekerabatan yang mendasar dalam masyarakat.

Status sosial pada ekonomi keluarga ini pada setiap lingkungan masyarakat dengan sengaja atau tidak sengaja terbentuk dengan sendirinya dalam kontek ini Soekanto mengutip keterangan Aris toteles: "Bahwa di dalam tiap-tiap negara terdapat tiga unsur, yaitu mereka yang kaya sekali, mereka yang melarat dan mereka yang ada di tengahtengahnya".

Ucapan demikian sedikit banyak membuktikan bahwa dizaman itu, mempunyai kedudukan yang bertingkat tingkat dari bawah ke atas. Seorang sosiolog terkemuka yaitu Pitirim A. Sorokin, mengatakan:

Mengatakan bahwa sistim lapisan merupakan ciri yang tetap dan umum bagi masyarakat yang hidup teratur. Barangsiapa yang memiliki barang yang berharga dalam jumlah yang sangat banyak di angap dalam masyarakat kelasa atasan. Mereka yang hanya sedikit 
memiliki sesuatu yang berharga dalam pandangan masyarakat mempunyai kedudukan yang rendah. Di antara lapisan yang atasan dan lapisan yang rendah ada lapisan yang jumlahnya dapat di tentukan sendiri oleh mereka yang hendak mempelajari sistem lapisan masyarakat itu.

\section{Kedudukan Perempuan Dalam Menafkahi Keluarga}

Nafkah adalah pemberi kebutuhan pokok dalam hidup dari seorang suami kepada istrinya. Dengan demikian, nafkah istri berarti pemberian yang wajib dilakukan oleh suami kepada isterinya dalam masa perkawinannya. Tugas utama ibu rumah tangga adalah mengurus rumah tangga dan keluarga. Bertanggung jawab atas kegiatan kebersihan dan kerapian di rumah. Adapun kedudukan ibu di dalam keluarga anatar lain pendamping suami, penjaga harta benda yang ada dirumahnya, pendidik untuk putra-putrinya, sebagai pengganti kedudukan ayah, bila ayah tiada.

Kedudukan Ibu sangat penting dalam rumah tangga, kedudukan sebagai ibu rumah tangga. Ibu juga mempunyai kewajiban membimbing dan mendidik anak-anak. Setiap hari, ibu selalu menyediakan makanan bergizi agar seluruh anggota keluarga sehat. Ibu juga memasak dan menyelesaikan tugas ibu rumah tangga yang lain. Namun jika ada pembantu rumah tangga, maka tugas ibu terbantu. Meskipun tugas ibu banyak, ibu tidak pernah mengeluh, bahkan tetap penuh dengan kasih sayang dan perhatian, Ibu tetap melaksanakan tugasnya dengan baik. Disamping itu, ibu merupakan pendamping suami dikala suka maupun duka. Bagaimanapun keadaan suami, ibu harus tetap mendampingi suami. Oleh karena itu, sudah sepantasnya kita menghormati dan menyayangi ibu dengan mengikuti nasihat dan perintahnya.

Seperti yang telah dijelaskan, bahwa didalam keluarga seorang ayah mempunyai kedudukan sebagai kepala keluarga. Kepala keluarga bertanggung jawab atas keselamatan dan kesejahteraan anggota keluarganya. Tugas pokonya ayah adalah bekerja mencari nafkah untuk memenuhi kebutuhan keluarga. Namun, disini ada juga ibu yang ikut bekerja untuk memenuhi kebutuhan hidup bersama. Dengan perkembangan jaman yang semakin maju dan semamkin meningkatnya kebutuhan pokok keluarga, kedudukan perempuan disini bertambah seperti keikutsertaan ibu membantu suami memenuhi kebutuhan keluarga. Kedudukan 
perempuan (ibu rumah tannga) tidak berubah tetapi bertambah dengan ikut bekerja membantu suami.

Sebenarnya suami yang berkewajiban memberi nafkah kepada keluarga atau rumah tangganya. Wanita diperbolehkan untuk memberi nafkah kepada suami, anak, atau rumah tangganya dari hasil jerih payahnya, meskipun manafkahi keluarga itu merupakan kewajiban mutlak bagi si suami, asal wanita tersebut rela dalam hal ini. Meski perempuan pekerja itu mempunyai peran membantu suami mencari nafkah, dalam wilayah domestik rumah tangga ibu mempunyai peran dan tanggung jawab dalam menciptakan keluarga sakinah, dan ini sesungguhnya tidak dapat dipisahkan dari peran dan tanggung jawab pria. Tidak dapat dikatakan yang satu dominan dan lebih menentukan, sedang yang lain sekedar pelengkap, keduanya saling melengkapi dan saling mendukung.

Tanggung jawab perempuan secara umum adalah menjadi istri dan ibu rumah tangga. Tetapi bila ada perempuan yang bekerja mencari nafkah di luar rumah, bukan berarti ia lari dari tanggung jawabnya. Perempuan yang bekerja pun masih merasa dirinya adalah seorang istri dan ibu dari anak-anakanya. Semua yang lakukan itu demi keluarga. Pada dasarnya semua itu berat. Karier juga berat karena semata-mata demi keluarga, menjadi ibu rumah tangga, tidak mau meninggalkan rumah pun di rasa penting, antara pekerja dan mengendalikan rumah tangga itu sama-sama pentingnya.

Bila seorang perempuan berkehendak untuk memainkan perannya di atas, maka yang perlu diperhatikan adalah menyadarinya bahwa itu bukanlah hal yang mudah. Karena tugas utama baginya adalah sebagai istri dan ibu. Istri yang baik dapat menjadi pendamping suami yang berhasil, sedangkan ibu yang baik akan menghasilkan generasi yang handal untuk keluarganya, bangsa, dan umat.

\section{Pembahasan}

\section{Letak Geografis}

Desa Pinggan di Kecamatan Kintamani merupakan salah satu desa Bali Aga, dengan kekayaan sejarah yang dimiliki, antara lain keberadaan Pura Dalem Balingkang, yang merupakan pura Hindu tertua di Bali sebagai bekas pusat kerajaan Puri Dalem Balingkang. 
Desa ini terletak di ketinggian di atas $1.400 \mathrm{~m}$ dari permukaan laut dan Desa Pinggan berada pada daerah dataran tinggi dengan kondisi topografi tanah yang memiliki kemiringan yang cukup ke arah selatan. Desa Pinggan memiliki iklim pegunungan dengan musim hujan antara bulan Januari-Maret dan November-Desember. Curah hujan tertinggi antara bulan Desember- Januari dengan intensitas curah hujan mencapai $200-300 \mathrm{~mm} /$ tahun. Jenis tanah di Desa Pinggan adalah tanah regosol cokelat kelabu yang merupakan jenis tanah vulkanik berupa pasir, debu, kerikil, dan batu hasil letusan gunung berapi dengan luas areal 1560 Ha. Dilihat dari lingkungan wilayahnya Desa Pinggan berbatasan batas wilayah desa pinggan sebelah utara Desa Siakin, sebelah selatan Desa Songan, sebelah barat Desa Sukawana dan sebelah timur Desa Blandingan. Dilihat dari jarak tempuhnya Desa Pinggan berada cukup jauh dari pusat pemerintahan Kabupaten maupun Provinsi. Jarak dari pusat pemerintahan kecamatan kurang lebih 15 km, jarak dari ibu kota kabupaten kurang lebih 40 km dan jarak dari ibu kota provinsi kurang lebih $81 \mathrm{~km}$.

\section{Penduduk dan Demografi}

Jumlah penduduk Desa Pinggan saat ini adalah 2.018 orang, dengan rincian sebagai berikut; jenis kelamin laki-laki dengan jumlah 1.012 orang, perempuan 1.006 orang, dengan jumlah kepala keluarga sebanyak 677 kepala keluarga.

a. Jumlah Penduduk Berdasarkan Jenis Kelamin

\begin{tabular}{|c|c|}
\hline Jenis Kelamin & Jumlah \\
\hline Laki - Laki & 1.012 Orang \\
\hline Perempuan & 1.006 Orang \\
\hline Total & 2018 Orang \\
\hline
\end{tabular}

b. Jumlah Penduduk Menurut Agama 
Jurnal Sewaka Bhakti

Lembaga Penelitian dan Pengabdian Kepada Masyarakat Universitas Hindu Indonesia Denpasar Volume 4, Nomor 1 April 2020 ISSN: 2654-2935 (Online)

https://ejournal.unhi.ac.id/index.php/sewakabhakti

\begin{tabular}{|l|l|c|}
\hline No & \multicolumn{1}{|c|}{ Nama Agama } & Jumlah \\
\hline 1 & Hindu & 1.838 orang \\
\hline 2 & Islam & - \\
\hline 3 & Kristen & - \\
\hline 4 & Budha & - \\
\hline 5 & Kepercayaan lainnya & 2.018 orang \\
\hline \multicolumn{2}{|c|}{ Jumlah } & \\
\hline
\end{tabular}

pp. 21-35

Sumber: Data demogdrafi desa tahun 2019

\section{c. Jumlah Penduduk Menurut Mata Pencarian}

\begin{tabular}{|c|l|c|}
\hline No & Jenis Mata Pencaharia & Jumlah \\
\hline 1 & Petani & 1.730 orang \\
\hline 2 & Pertukangan & 90 orang \\
\hline 3 & Pegawai Negeri Sipil & 11 Orang \\
\hline 4 & Pedagang & 40 Orang \\
\hline 5 & ABRI/POLRI & 7 Orang \\
\hline 6 & Karyawan Swasta & 10 Orang \\
\hline \multicolumn{2}{|c|}{ Jumlah } & 1838 Orang \\
\cline { 2 - 3 } & &
\end{tabular}

Sumber: Kantor Desa Pinggan

\section{Keadaan Ekonomi dan Sosial Budaya Desa Pancasari}

Mata pencaharian yang digeluti oleh penduduk setempat sebagian besar adalah sebagai buruh petani yakni dengan jumlah hingga 785 orang. Namun demikian ada bebearapa 
profesi lain yang dijadikan sebagai mata pencaharian oleh penduduk setempat yakni meliputi Pegawai swasta dengan jumlah 215 orang, Kehidupan sosial penduduk Desa Pancasari dapat digolongkan masih asli dengan kehidupan khas agrarisnya yang masih menggunakan konsep Tri Hita Karana sebagai konsep menjalankan kehidupan sosialnya. Konsep ini diterapkan mulai dari pola pemukiman penduduk setempat dimana perwujudannya dapat dilihat dari pengaturan ruang. Setiap pekarangan rumah dapat dipisahkan menjadi tiga bagian, yaitu parahyangan (hulu), pawongan (tengah) dan palemahan (hilir) yang bermakna wawasan lingkungan hidup.

Konsep Parahyangan digunakan dalam membangun tempat suci atau pura keluarga.Letak Pura atau sanggah ini biasanya di arah timur laut.Arah ini diyakini memiliki arti letak yang bagus untuk menjaga hubungan antara manusia dengan Tuhan Yang Maha Esa.Konsep Pawongan digunakan dalam menentukan letak tempat tinggal dimana aktivitas anggota keluarga berlangsung dimana letaknya adalah ditengah-tengah.Bentuk dan Lokasi bangunan diklasifikasikan berdasarkan fungsinya, yang terdiri dari Bale Daja dan Dangin (bangunan di sebelah selatan dan timur).Bale Dauh (bangunan disebelah barat) dimanfaatkan untuk bangunan tempat berkumpulnya keluarga. Tempat ini biasanya terletak dekat dengan pintu masuk karena tempat ini juga sekaligus berfungsi sebagai daerah keamanan. Bale Delod (bangunan di sebelah utara) berfungsi sebagai tempat untuk melakukan upacara kehidupan duniawi. Konsep palemahan disediakan untuk menempatkan tumbuh-tumbuhan dan hewan sebagai manifestasi keselarasan hubungan antara manusia dengan lingkungan. Demikian masyarakat Desa Pancasari menjaga keseimbangan hubungan dengan Tuhan, dengan sesama manusia dan dengan lingkungan.

\section{Kegiatan Ibu Rumah Tangga Dalam Usaha Berdagang}

Masyarakat Desa Pinggan merupakan masyarakat pedesaan yang kegiatan ekonominya terdiri dari berbagai bidang, baik bidang jasa tenaga kerja, pedagang, petani dan lainnya. Masyarakat pedesaan ini persaingan ekonominya sangat ketat, hal ini dipengaruhi oleh lingkungan tempat mereka tinggal. Walaupun dihadapi dengan persaingan yang ketat, masyarakat desa perlu memacu diri agar dapat bertahan dalam persangingan tersebut, sebagaimana yang dilakukan oleh sebagian masyarakat desa pinggan, yaitu partisipasi perempuan dalam kegiatan usaha berdagang. Partisipasi ibu rumah tangga dalam kegiatan 
ekonomi keluarga adalah upaya mencari kemandirian ekonomi dan menjadi pedagang lebih baik lagi. Hasil usaha tersebut membantu suami dalam memenuhi kebutuhan keluarga, seperti kebutuhan makan, pakaian, pendidikan, dan lainnya. Berikut data perempuan usaha dagang di Desa Pinggan. Memperoleh pendapatan dari berdagang antara Rp 1.000.000 hingga Rp 15.000.000 setiap bulannya.

\section{Persentase Profesi Perempuan Di Desa Pinggan}

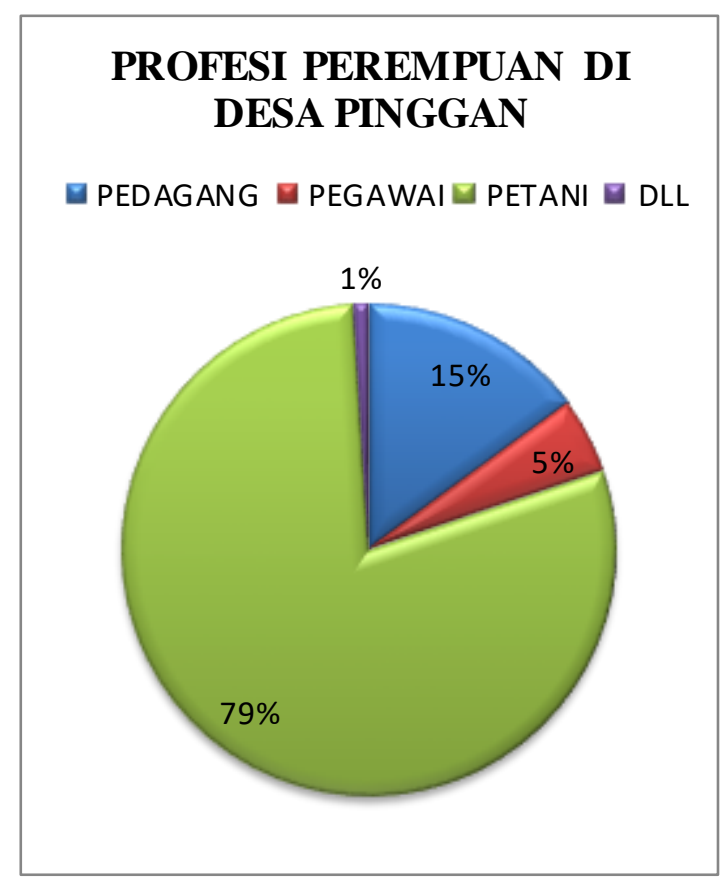

Sumber:Wawancara Prebekel Desa Pinggan

Data di atas merupakan data para ibu rumah tangga dengan hasil penjualan (-/+) Rp. 50.000/harinya. Jumlah penjualnnya berbeda-beda, sehingga pendapatan pun berbeda-beda disesuaikan dengan barang yang di jual. Sektor usaha berdagang merupakan salah satu sektor usaha yang membatu meringankan perekonomian keluarga.

Pemenuhan kebutuhan rumah tangga merupakan tanggung jawab suami, baik dalam pemenuhan ekonomi, pendidikan dan tempat tinggal. Namun seiring dengan pertumbuhan ekonomi dan penduduk tentunya akan berpengaruh pada kebutuhan rumah tangga yang terus meninggkat. Hal ini bisa ditinjau dari nilai harga barang serta biaya pendidikan yang terus 
meningkat. Atas alasan tersebut, maka peran perempuan dibutuhkan untuk membantu suami memenuhi ekonomi keluarga.

Tujuan dari peran ibu rumah tangga dalam membantu ekonomi keluarga adalah membantu keluarga agar lebih berdaya sehingga tidak hanya dapat kemampuan dengan memanfaatkan potensi yang dimilikinya, tetapi juga kemampuan ekonominya. Maka keterlibatan perempuan dalam membantu ekonomi keluarga adalah dengan memberi kesempatan kepada ibu-ibu rumah tangga baik berupa modal maupun pengetahuan berdagang, bertani sehingga mereka mampu memanfaatkan sumber daya alam yang ada dengan benar.

Peran perempuan dalam membantu ekonomi keluarga tidak semata untuk membantu ekonomi keluarga saja, melainkan juga membentuk kualitas diri perempuan itu sendiri. Upaya membentu kualitas perempuan dalam membantu ekonomi yaitu dengan memberi kesempatan bagi perempuan dalam sektor ekonomi, seperti kesempatan kerja dan usaha mandiri.

Usaha bertani dan berdagang yang ada di Desa pinggan kintamani merupakan kegiatan utama yang dilakukan oleh para perempuan yang ada di desa pinggan. Seperti yang disampaikan oleh bapak I Ketut Janji "hampir semua perempuan yang ada di desa pinggan ikut bekerja membantu suami. Baik itu bekerja sebagai petani maupun sebagai pedagang." Hal ini dikarenakan banyak keluarga di Desa pingan memiliki kebun dengan luas yang sangat banyak dan juga pendidikan yang tebatas dan perekonomian yang kurang memadai maka nya perlu peran ibu rumah tangga dalam membantu suami memenuhi kebutuhan keluarganya.'Pendapatan yang disampaikan oleh Bapak Prebekel Desa Pinggan tersebut sejalan dengan fakta lapangan saat peneliti lakukan melakuakan observasi bahwa kegiatan bertani dan berdagang dilakukan dirumah dan di kebun. Dan pelaku industrinya pun adalah perempuan yang merupakan ibu rumah tangga. Bagi para perempuan di desa pinggan, kegiatan ini mereka lakukan tidak sebatas untuk membantu ekonomi keluarga atau membantu suami menafkahi keluarga, melainkan juga guna sebagai sarana mengembangkan diri dan menumbuhkan kemandirian. Seperti yang di ungkapkan Ibu nengah rata: "Usaha bertani yang 
saya tekuni untuk membantu ekonomi keluarga, juga untuk mengembangkan diri dan menumbuhkan kemandirian ibu-ibu rumah tangga".

Peran perempuan dalam membantu ekonomi keluarga diimplementasikan melalui kegiatan bertani dan berdagang secara baik. Disampaikan juga, kegiatan usaha tersebut bukan hanya sebatas membantu pendapatan keluarga, tetapi juga sebagai sarana mengembangkan potensi diri dan menjalin siratuhrahmi dengan baik lagi dengan masyarakat. Pudjiwati, 1993, upaya menyertakan perempuan dalam proses pembangunan bukan hanya merupakan hal yang bersifat manusiawi tetapi juga merupakan tintakan yang efisien. Model penyuluhan yang tepat sasaram ke khalayak sasaran tentunya penting juga diperhatikan (Sastra Wibawa, 2018).

\section{Kesimpulan dan Saran}

\section{Simpulan}

Berdasarkan pembahasan diatas, maka diperoleh simpulan bahwa peran perempuan dalam membantu ekonomi keluarga melalui usaha dagang oleh perempuan di Desa pinggan dilakukan di pasar maupun di rumah, secara mandiri baik secara pencarian barang. Kegiatan usaha dagang yang dilakukan oleh para perempuan di Desa Pinggan merupakan suatu upaya membantu ekonomi keluarga yang bertujuan untuk memenuhi kebutuhan keluarga serta mengembangkan potensi dirinya, sehingga terjadi perubahan kondisi dari tidak berdaya menjadi berdaya. Indikator perubahan tersebut ditinjau dari hasil usaha berdagang. Kegiatan yang dilakuka oleh para pedagang, tetapi banyaknya penjualan menjadikan hasilannya berbeda-beda. Dampak peran ganda perempuan sebagai pedagang di Desa Pinggan terhadap keluarga memberikan dampak yang besar terutama dalam memenuhi kebutuhan sehari-hari, seperti kebutuhan makan, biaya pendidikan dan kebutuhan rumah tangga lainnya. Dalam menjalankan peran sebagai istri, ibu rumah tangga dan juga perannya sebagai perempuan bekerja, para pedagang ikan tidak melepaskan tanggung jawabnya terhadap perannya dalam keluarga. Sebelum melaksanakan aktifitas bekerja, mereka mendahulukan menyelesaikan kegiatan rumah, seperti bersih-bersih rumah, menyiapkan sarapan, mencuci pakaian dan sebagainya. Setelah kegiatan tersebut selesai, maka barulah mereka memulai aktifitas berkerja sebagai pedagang kerja. Upaya yang dilakukan para pedagang dalam menghindari 
Lembaga Penelitian dan Pengabdian Kepada Masyarakat Universitas Hindu Indonesia Denpasar Volume 4, Nomor 1 April 2020 ISSN: 2654-2935 (Online)

https://ejournal.unhi.ac.id/index.php/sewakabhakti pp. 21-35 konflik keluarga yaitu dengan membangun komunikasi kepada internal keluarganya, Karena aktifitas usaha dagang yang mereka lakukan merupakan kegiatan yang dilakukan di sekitaran Desa Pinggan. Oleh karenanya para perempuan perlu memintak izin terlebih dahulu, suami dan anak dalam menjalankan kegiatan tersebut, sehingga dalam menjalankan aktifitas bekerja sebagai pedagang mendapatkan dukungan dengan baik materi maupun moril. Kegiatan bekerja membantu suami untuk ikut mencari nafkah maka pada kesempatan lain ibu-ibu rumah tangga Desa Pinggan juga tidak pernah lupa untuk menjalankan kegiatan keagamaan maupun budaya yang ada di Desa Pinggan.

\section{Saran}

Peranan perempuan dalam membantu perekonomian keluarga sangatlah penting. Diharapkan perempuan yang ada di Desa Pinggan agar dapat membagi waktu untuk usaha, untuk keluarga, serta mengoptimalkan kemampuan diri untuk mendidik dan membesar anak, berusaha rutin menyisihkan pendapatan untuk ditabung guna pendidikan anak, memahami strategi berdagang yang baik, sehingga usaha dagang dan bertani dapat lebih berkembang dan memberikan dampak positif terhadap lingkungan sekitar. menjalankan kerja sama dengan sesama pedagang dan dinas kebersihan pasar, agar kebersihan sekitarnya tidak tercemar.

\section{Daftar Pustaka}

Achmad, S. (1994). Peningkatan Peranan Wanita dalam Pembangunan. Jakarta: Kantor Menteri UPWRI.

Fungsi keluarga menurut BKKBN (1992). (n.d.). Retrieved from https://www.scribd.com/doc/7881592/Fungsi-Keluarga-

Hikmatuz Zoleha Sayyong. (2012). Fungsi Keluarga Menurut BKKBN. Retrieved July 20, 2018, from https://www.scribd.com/doc/78815992/Fungsi-Keluarga-Menurut-BKKBN

M.Muhajir, D. (2005). Negara dan Perempuan. Yogyakarta: Media Wacana.

Pudjiwati, S. (1993). Peranan Wanita dan Pembangunan Masyarakat Desa. Jakarta: Kanisius.

Sastra Wibawa, I. P. (2018). PENYULUHAN HUKUM PERKAWINAN HINDU SEBAGAI STRATEGI MENUJU DESA SADAR HUKUM. Sewaka Bhakti, 1(1), 1-7. Retrieved from https://ejournal.unhi.ac.id/index.php/sewakabhakti/article/view/16/2 